Brit. J. industr. Med., 1963, 20, 181.

\title{
DUST AND COLLAGEN CONTENT OF LUNGS OF COAL-WORKERS WITH PROGRESSIVE MASSIVE FIBROSIS
}

\author{
BY \\ G. NAGELSCHMIDT, D. RIVERS*, E. J. KING $\dagger$, and W. TREVELLA \\ From the Safety in Mines Research Establishment, Ministry of Power, Sheffield, the Pneumoconiosis \\ Research Unit, Llandough Hospital, Nr. Penarth, Glam., and the Postgraduate \\ Medical School of London, Ducane Road, London
}

(RECEIVED FOR PUBLICATION DECEMBER 14, 1962)

\begin{abstract}
In order to test the silica theory of the origin of progressive massive fibrosis (P.M.F.) in coalminers' pneumoconiosis, separate dust analyses have been made of the massive lesions and of the rest of the lung from 18 coal-workers with P.M.F. who had been employed in several coalfields. The dry weight of the massive lesions ranged from 5 to over $100 \mathrm{~g}$. and the dust concentration in the P.M.F. lesions was on an average twice as high as in the rest of the lung. It was found that the quartz percentage of the lung dust was almost identical in the two samples from each lung (Table 3). The quartz content of the average lung dust (P.M.F. and "rest of lung") of 32 cases of P.M.F. was compared with that of 58 cases of simple pneumoconiosis. The quartz content of the P.M.F. dust was slightly higher but, allowing for variable dust composition in different coalfields, the difference was not significant (Table 8). The silica theory of P.M.F. cannot be supported by this study.

Comparisons of the collagen content of the P.M.F. lesions and of the rest of the lung in 17 lungs and of lesions of P.M.F. and of simple pneumoconiosis in 31 and 27 lungs, respectively, showed no clear difference between any of the groups and surprisingly low values for the massive lesions. A possible way in which this result could be reconciled with the histopathological observations is suggested. One gram of coal-mine dust produced, on an average, $0.4 \mathrm{~g}$. of extra collagen. In five silicotic lungs, where the lung dust contained 15 to $50 \%$ of free silica, $1 \mathrm{~g}$. of dust produced between 2 and $7 \mathrm{~g}$. of extra collagen.
\end{abstract}

In continuation of studies of the dust content and composition of the lungs of coal-workers with simple pneumoconiosis (Rivers, Wise, King, and Nagelschmidt, 1960), a number of lungs with progressive massive fibrosis (P.M.F.) have been analysed. The pathological features of P.M.F. have been presented by Gough (1940), Fletcher and Gough (1950), and Heppleston (1951). These authors describe the lesion as a rubbery hard, heavily dusted, pigmented mass of tissue which on microscopic examination appears to consist largely of collagenous fibres with abundant black dust particles between the fibres. Small, heavily pigmented fibrous nodules are frequently seen distributed around the periphery of the P.M.F. lesion. Cochrane (1960) has reviewed the different theories

* Now at the Coventry Laboratory, Coventry and Warwickshire Hospital, and in receipt of a research grant from the Medical Research Council

†Died October 31, 1962 of the aetiology of P.M.F. and the most prominent of these are the "silica" and "tuberculosis" theories. Cochrane's recent work (1962) shows that the attack rate of P.M.F. rises steeply with increasing $x$-ray change above category 1 . This suggests (Rivers $e t$ al., 1960) that the attack rate is related to the total amount of dust in the lung, what may be called the "total dust hypothesis", and/or to a higher non-coal content of the lung dust. Analysis of the dust content and composition of the massive lesion alone and of the rest of the lung separately should reveal whether the quartz content of the dust is higher in the lesion than in the rest of the lung, and whether it is higher in P.M.F. lungs than in the lungs of coal-workers with simple pneumoconiosis. This paper includes a study of the collagen content of the P.M.F. lesion and of the rest of the lung separately and of the total collagen content of another group of P.M.F. lungs and of a number of lungs with simple pneumoconiosis. 


\section{Material}

Formalin-fixed necropsy specimens of whole lungs were provided by pathologists from different coalfields, and the following groups were used for the comparative study of the amount and composition of lung dust and of collagen content.

\section{Progressive Massive Fibrosis}

Group 1a.-In 18 lungs with P.M.F., the entire lesion (or lesions) and the rest of the lung were analysed separately. The series was made up of nine lungs from the Durham, four from the South Wales, three from the Scottish, and two* from the Ruhr coalfields.

Group 1b.-Fourteen lungs with P.M.F. from South Wales were analysed for their total collagen content. (Their dust content and its composition have already been reported by King, Maguire, and Nagelschmidt, 1956.)

\section{Simple Pneumoconiosis}

Group 2a.-Thirty-two lungs with simple pneumoconiosis had a total dust content in excess of $4 \mathrm{~g}$. (from the series of 45 lungs described by Rivers et al., 1960).

Group 2b.-Twenty-six other lungs with simple pneumoconiosis were obtained, nine from South Wales, six from Durham, and 11 from the Scottish coalfields. Groups $2 \mathrm{a}$ and $2 \mathrm{~b}$ thus made up a total of 58 lungs. All these lungs were used for comparison of the total dust and quartz content of simple pneumoconiosis lungs with that of the P.M.F. groups.

Group $2 c$.-A selection of 27 lungs with simple pneumoconiosis from groups $2 \mathrm{a}$ and $2 \mathrm{~b}$ was analysed for collagen for comparison with the P.M.F. lungs. The lungs were chosen to match the P.M.F. lungs as far as possible for amount of dust, quartz content, age, and coalfield.

The P.M.F. lungs represented a wide range of size of lesion; cases with obvious tuberculosis or tumour were excluded. The lungs with simple pneumoconiosis also represented a wide range of dust content and again those with tuberculosis or tumour were excluded. Cases showing gross discrepancies between the right and left lung were also excluded, but such discrepancies were rare.

The dust and collagen content of five silicotic lungs from other industrial exposures, sand blasting, fettling, and slate mining, obtained for dust analysis from various pathologists, was also measured.

\section{Technique}

Pathology.-The gross appearances of the lungs were noted, the greatest and smallest diameters of the P.M.F. lesion in the sagittal plane were measured, and their product was taken to give an approximate estimate of the area of the lesion. Where two or more P.M.F. lesions occurred in the same lung, the areas were added to give an estimate of the total area of P.M.F. In only one lung (case 1, Table 1) was there cavitation with fluid, but the fluid was carefully saved and included for dust analysis. Blocks of tissue from both lungs representative of the

*Kindly provided by Professor K. Thomas of Göttingen gross pathology were taken for histological examination. Serial histological sections were stained with haematoxylin and eosin, by the Weigert and van Gieson method for collagen, and by a silver impregnation technique for reticulin. One whole lung, except for these blocks, was freed as carefully as possible from the larger bronchi, vessels, and lymph glands and used for dust analysis. In some cases of P.M.F., however, it was not possible to dissect away all peribronchial lymph glands since they were indistinguishable from the P.M.F. lesion as a whole. For the 18 cases of group 1a it was found possible to separate digitally the firm P.M.F. lesion from the surrounding spongy tissue of the lung. Similarly, it was found possible to enucleate the fibrous dust nodules which were particularly abundant in case 16 (Table 1).

Dust and Collagen Analyses.-The tissues were dried and ground and samples were analysed for coal, quartz, and "other minerals", mainly kaolin and mica, by the methods described previously (Rivers et al., 1960).

Collagen in the samples was determined as follows: The dried lung was hydrolysed with hot hydrochloric acid under pressure, and in the neutralized filtrate total hydroxyproline was determined by the method of Stegemann (1958). Multiplication by 7.5 gave a value for collagen based on the assumption that collagen contains $13 \cdot 3 \%$ of hydroxyproline (Neuman and Logan, 1950). Collagen determinations were made on the lungs of groups $1 \mathrm{a}, 1 \mathrm{~b}$, and $2 \mathrm{c}$ and also on the few silicotic lungs.

\section{Results}

\section{Progressive Massive Fibrosis}

Dust Composition and Concentration of P.M.F. Lesion and of "Rest of Lung".--In Table 1, ages, dust exposure years, dried weights and areas of P.M.F. lesions, and dried weights of "rest of lung" and whole lungs are given. The results are listed in decreasing order of weight of the P.M.F. lesions. The proportions of the total lung weight which these lesions represent are also given; they range from 5 to $61 \%$ of the total lung weights, including the dust. For all the smaller and some of the larger lesions the estimated areas in $\mathrm{cm}^{2}$. were similar to the dry weights in grams.

Table 2 shows the amounts of dust in grams and as per cent dry weight in P.M.F. lesions, rest of lung, and whole lungs. The dust concentration was, on an average, twice as high in the P.M.F. lesion as in the rest of the lung (mean $2 \cdot 13$, range $1 \cdot 5$ to $2 \cdot 9$ ). Figure 1 shows the weight of dust in the lung plotted against age at death and suggests a negative correlation since four out of five cases with more than $20 \mathrm{~g}$. of dust had died before the age of 60 years. The total dust was less than $10 \mathrm{~g}$. in five of the lungs; using the data of Rivers et al. (1960), lungs nos. 17 and 18 would correspond to $x$-ray categories 0 or 1 .

Coal and quartz percentages of the lung dust in 
TABLE 1

PROGRESSIVE MASSIVE FIBROSIS (GROUP 1a): WEIGHTS, INCLUDING THE DUST, OF P.M.F. LESIONS, OF THE REST OF THE LUNG, AND OF THE WHOLE LUNGS

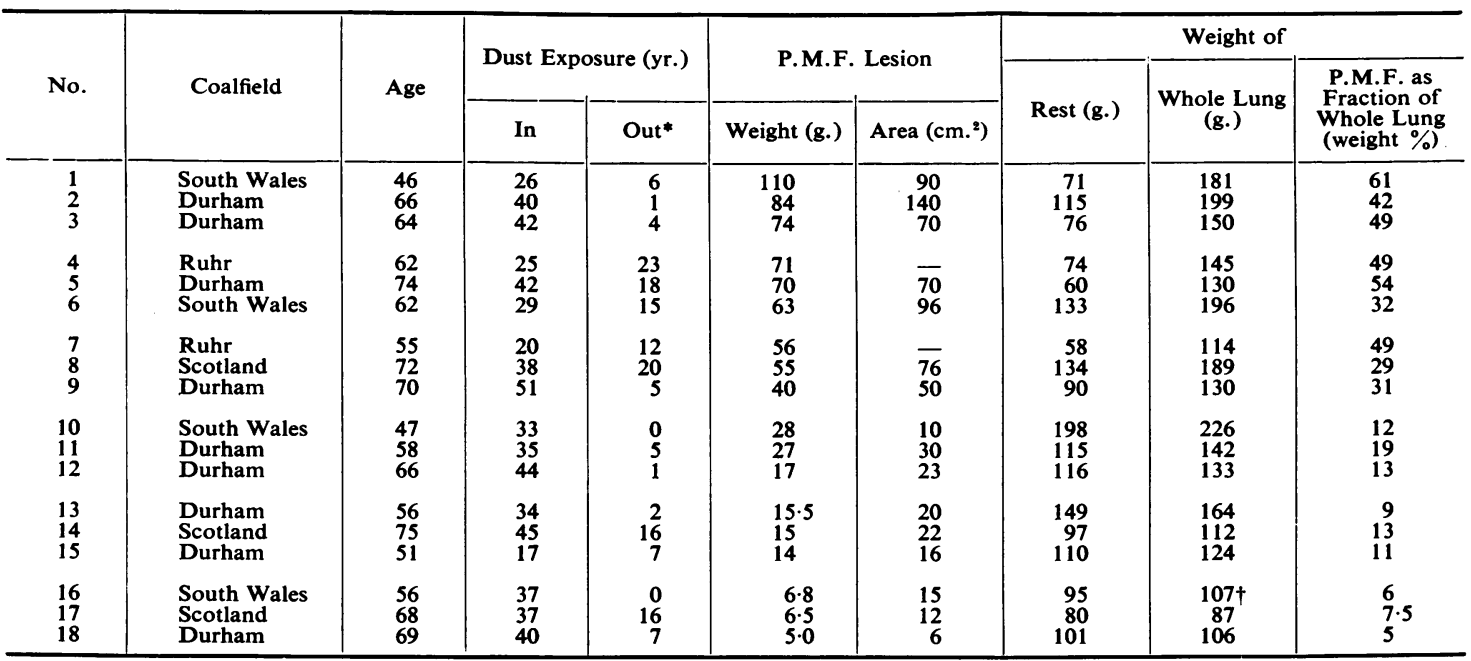

*Number of years between the end of dust exposure and death.

$\dagger$ Includes fibrous nodules: $5 \mathrm{~g}$. with $1 \cdot 2 \mathrm{~g}$. of dust.

TABLE 2

PROGRESSIVE MASSIVE FIBROSIS: TOTAL DUST IN GRAMS AND AS PER CENT DRIED LUNG IN SEPARATE PORTIONS AND IN WHOLE LUNGS

\begin{tabular}{|c|c|c|c|c|c|c|c|}
\hline \multirow{2}{*}{ No. } & \multicolumn{3}{|c|}{ Total Dust in } & \multicolumn{3}{|c|}{ Total Dust as $\%$ Dried Tissue in: } & \multirow{2}{*}{ Ratio $\mathbf{a} / \mathbf{b}$} \\
\hline & P.M.F. (g.) & Rest (g.) & Whole Lung (g.) & P.M.F. (a) & Rest (b) & Whole Lung & \\
\hline $\begin{array}{l}1 \\
2 \\
3\end{array}$ & $\begin{array}{l}28 \cdot 9 \\
18 \cdot 2 \\
14 \cdot 1\end{array}$ & $\begin{array}{r}10.7 \\
12.2 \\
5.9\end{array}$ & $\begin{array}{l}39 \cdot 6 \\
30 \cdot 4 \\
20 \cdot 0\end{array}$ & $\begin{array}{l}26 \cdot 3 \\
21 \cdot 6 \\
19 \cdot 1\end{array}$ & $\begin{array}{r}15.0 \\
10.6 \\
7.7\end{array}$ & $\begin{array}{l}21.9 \\
15.3 \\
13.4\end{array}$ & $\begin{array}{l}1 \cdot 8 \\
2.0 \\
2.5\end{array}$ \\
\hline $\begin{array}{l}4 \\
5 \\
6\end{array}$ & $\begin{array}{r}14.4 \\
4.4 \\
8.8\end{array}$ & $\begin{array}{l}5 \cdot 3 \\
1.6 \\
9.7\end{array}$ & $\begin{array}{r}19.8 \\
6.0 \\
18.5\end{array}$ & $\begin{array}{r}20.2 \\
6.2 \\
13.9\end{array}$ & $\begin{array}{l}7 \cdot 2 \\
2 \cdot 6 \\
7 \cdot 3\end{array}$ & $\begin{array}{r}13.6 \\
4.6 \\
9.4\end{array}$ & $\begin{array}{l}2 \cdot 8 \\
2 \cdot 4 \\
1.9\end{array}$ \\
\hline $\begin{array}{l}7 \\
8 \\
9\end{array}$ & $\begin{array}{r}15.9 \\
7.5 \\
8.8\end{array}$ & $\begin{array}{l}9 \cdot 8 \\
7 \cdot 4 \\
9 \cdot 1\end{array}$ & $\begin{array}{l}25 \cdot 7 \\
14 \cdot 9 \\
17 \cdot 9\end{array}$ & $\begin{array}{l}28.4 \\
13.7 \\
21.9\end{array}$ & $\begin{array}{r}16 \cdot 8 \\
5.5 \\
10 \cdot 1\end{array}$ & $\begin{array}{r}22.4 \\
7.9 \\
13.8\end{array}$ & $\begin{array}{l}1 \cdot 7 \\
2 \cdot 5 \\
2 \cdot 2\end{array}$ \\
\hline $\begin{array}{l}10 \\
11 \\
12\end{array}$ & $\begin{array}{l}6.5 \\
2.6 \\
2.9\end{array}$ & $\begin{array}{r}27.9 \\
4.0 \\
9.5\end{array}$ & $\begin{array}{r}34 \cdot 4 \\
6.6 \\
12.4\end{array}$ & $\begin{array}{r}23 \cdot 3 \\
9 \cdot 8 \\
17 \cdot 4\end{array}$ & $\begin{array}{r}14 \cdot 1 \\
3 \cdot 4 \\
8 \cdot 2\end{array}$ & $\begin{array}{c}15 \cdot 2 \\
4 \cdot 65 \\
9 \cdot 3\end{array}$ & $\begin{array}{l}1.7 \\
2.9 \\
2.1\end{array}$ \\
\hline $\begin{array}{l}13 \\
14 \\
15\end{array}$ & $\begin{array}{l}3 \cdot 2 \\
2 \cdot 3 \\
1 \cdot 5\end{array}$ & $\begin{array}{r}18.9 \\
7.7 \\
5.3\end{array}$ & $\begin{array}{r}22.1 \\
10.0 \\
6.8\end{array}$ & $\begin{array}{l}20.9 \\
15.6 \\
10.6\end{array}$ & $\begin{array}{r}12.6 \\
7.9 \\
4.8\end{array}$ & $\begin{array}{r}13.5 \\
8.9 \\
5.5\end{array}$ & $\begin{array}{l}1.7 \\
2.0 \\
2.2\end{array}$ \\
\hline $\begin{array}{l}16 \\
17 \\
18\end{array}$ & $\begin{array}{l}1.4 \\
0.7 \\
0.5\end{array}$ & $\begin{array}{l}9 \cdot 1 \\
5.6 \\
4 \cdot 0\end{array}$ & $\begin{array}{r}11 \cdot 7 \\
6 \cdot 3 \\
4.5\end{array}$ & $\begin{array}{r}20.6 \\
10.8 \\
9.6\end{array}$ & $\begin{array}{l}9.6 \\
7.0 \\
3.9\end{array}$ & $\begin{array}{r}11 \cdot 0 \\
7 \cdot 3 \\
4 \cdot 2\end{array}$ & $\begin{array}{l}2 \cdot 2 \\
1 \cdot 5 \\
2 \cdot 5\end{array}$ \\
\hline
\end{tabular}

P.M.F. lesions and in "rest of lung" are given in Table 3. In most cases the values are almost identical for P.M.F. and rest of lung in spite of considerable variations between the lungs. The coal percentage ranged from $\mathbf{4 0}$ to $\mathbf{9 0}$ and the quartz percentage from 1 to 10 . Appreciable differences between P.M.F. and rest of lung were found in only two lungs; in no. 8 there was more coal and less quartz in the P.M.F. lesions than in the rest of the lung, whereas in no. 15 the opposite effect was observed. In Table 4 the total dust is expressed as per cent dust-free tissue for P.M.F., rest of lung, and for the whole lungs.

Tables 1 to 4 demonstrate clearly two effects. First, in a P.M.F. lung, and regardless of the size of the lesion, the dust composition in the P.M.F. lesion is the same as the dust composition in the rest of the lung, and secondly the dust concentration is higher; on average, it is about doubled in the P.M.F. lesion or, expressed as a percentage of the dust-free tissue, it is 2.4 times higher. Thus there is no evidence that 
TABLE 3

PROGRESSIVE MASSIVE FIBROSIS: COMPOSITION OF DUST IN SEPARATE PORTIONS AND IN THE WHOLE LUNGS

\begin{tabular}{|c|c|c|c|c|c|c|}
\hline \multirow{3}{*}{ No. } & \multicolumn{6}{|c|}{ Per cent Total Dust: } \\
\hline & \multicolumn{3}{|c|}{ Coal Per cent in } & \multicolumn{3}{|c|}{ Quartz Per cent in: } \\
\hline & P.M.F. & Rest & Whole Lung & P.M.F. & Rest & Whole Lung \\
\hline $\begin{array}{l}1 \\
2 \\
3\end{array}$ & $\begin{array}{l}91 \\
92 \\
89\end{array}$ & $\begin{array}{l}89 \\
92 \\
86\end{array}$ & $\begin{array}{l}90 \\
92 \\
88\end{array}$ & $\begin{array}{l}1.2 \\
1.7 \\
1.7\end{array}$ & $\begin{array}{l}1.4 \\
1.5 \\
1.4\end{array}$ & $\begin{array}{l}1.2 \\
1.6 \\
1.6\end{array}$ \\
\hline $\begin{array}{l}4 \\
5 \\
6\end{array}$ & $\begin{array}{l}78 \\
60 \\
88\end{array}$ & $\begin{array}{l}73 \\
60 \\
88\end{array}$ & $\begin{array}{l}78 \\
60 \\
87\end{array}$ & $\begin{array}{l}4 \cdot 1 \\
8 \cdot 8 \\
1 \cdot 8\end{array}$ & $\begin{array}{r}4.6 \\
10 \cdot 0 \\
2.6\end{array}$ & $\begin{array}{l}4 \cdot 2 \\
9 \cdot 1 \\
2 \cdot 3\end{array}$ \\
\hline $\begin{array}{l}7 \\
8 \\
9\end{array}$ & $\begin{array}{l}94 \\
95 \\
91\end{array}$ & $\begin{array}{l}94 \\
86 \\
87\end{array}$ & $\begin{array}{l}94 \\
91 \\
89\end{array}$ & $\begin{array}{l}0.8 \\
0.2 \\
1.6\end{array}$ & $\begin{array}{l}0.8 \\
1.5 \\
1.8\end{array}$ & $\begin{array}{l}0.8 \\
0.9 \\
1.7\end{array}$ \\
\hline $\begin{array}{l}10 \\
11 \\
12\end{array}$ & $\begin{array}{l}93 \\
83 \\
41\end{array}$ & $\begin{array}{l}92 \\
83 \\
42\end{array}$ & $\begin{array}{l}92 \\
83 \\
41\end{array}$ & $\begin{array}{r}1.4 \\
3.6 \\
10.6\end{array}$ & $\begin{array}{l}1 \cdot 5 \\
3 \cdot 6 \\
9 \cdot 4\end{array}$ & $\begin{array}{l}1.5 \\
3.6 \\
9.8\end{array}$ \\
\hline $\begin{array}{l}13 \\
14 \\
15\end{array}$ & $\begin{array}{l}94 \\
84 \\
67\end{array}$ & $\begin{array}{l}93 \\
84 \\
78\end{array}$ & $\begin{array}{l}93 \\
84 \\
76\end{array}$ & $\begin{array}{l}1 \cdot 6 \\
2 \cdot 1 \\
8 \cdot 5\end{array}$ & $\begin{array}{l}1 \cdot 7 \\
2 \cdot 2 \\
5 \cdot 5\end{array}$ & $\begin{array}{l}1 \cdot 7 \\
2 \cdot 2 \\
6 \cdot 2\end{array}$ \\
\hline $\begin{array}{l}16 \\
17 \\
18\end{array}$ & $\begin{array}{l}67 \\
91 \\
78\end{array}$ & $\begin{array}{l}68 \\
88 \\
79\end{array}$ & $\begin{array}{l}67 \\
88 \\
78\end{array}$ & $\begin{array}{l}5 \cdot 5 \\
1 \cdot 2 \\
4 \cdot 2\end{array}$ & $\begin{array}{l}4 \cdot 5 \\
2 \cdot 0 \\
4 \cdot 3\end{array}$ & $\begin{array}{l}4 \cdot 7 \\
1.9 \\
4 \cdot 3\end{array}$ \\
\hline
\end{tabular}

TABLE 4

PROGRESSIVE MASSIVE FIBROSIS: CONCENTRATION OF TOTAL DUST IN SEPARATE PORTIONS AND IN THE WHOLE LUNGS

\begin{tabular}{c|c|c|c|c}
\hline \multirow{2}{*}{ No. } & \multicolumn{3}{|c|}{ Total Dust as Per Cent Dust-free Tissue in: } \\
\cline { 2 - 3 } & P.M.F. (a) & Rest (b) & Whole Lung & Ratio a/b \\
\hline 1 & 36.7 & 17.7 & 28.0 & 2.1 \\
2 & 27.6 & 11.9 & 18.1 & 2.3 \\
3 & 23.6 & 8.3 & 15.5 & 2.8 \\
4 & 25.3 & 7.8 & 15.8 & 3.2 \\
5 & 6.7 & 2.7 & 4.8 & 2.5 \\
6 & 16.2 & 7.9 & 10.4 & 2.1 \\
7 & 39.5 & 20.2 & 28.8 & 2.0 \\
8 & 15.9 & 5.8 & 8.6 & 2.7 \\
9 & 28.0 & 11.2 & 16.0 & 2.5 \\
10 & 30.3 & 16.4 & 17.9 & 1.8 \\
11 & 10.7 & 3.5 & 4.9 & 3.1 \\
12 & 21.1 & 8.9 & 10.2 & 2.4 \\
13 & 26.5 & 14.5 & 15.5 & 1.8 \\
14 & 18.5 & 8.6 & 9.6 & 2.2 \\
15 & 11.9 & 5.1 & 5.8 & 2.3 \\
16 & 26.0 & 10.6 & 12.4 & 2.4 \\
17 & 12.1 & 7.5 & 7.9 & 1.6 \\
18 & 10.6 & 4.05 & 4.4 & 2.6 \\
\hline
\end{tabular}

the quartz percentage of the dust in large or small massive lesions is higher than the quartz percentage of the dust in the rest of the lung, but there is evidence of a higher proportion of dust to tissue in the P.M.F. lesions.

Collagen Content of P.M.F. Lesions and Rest of Lung.-The results of the collagen analyses are presented in two ways. Table 5 gives the amounts of collagen in grams in P.M.F., rest of lung, and their sum for each lung. Table 6 gives the results calculated as per cent dust-free tissue for P.M.F., rest of
TABLE 5

PROGRESSIVE MASSIVE FIBROSIS: COLLAGEN IN SEPARATE PORTIONS AND IN THE WHOLE LUNGS

\begin{tabular}{c|c|c|c}
\hline \multirow{2}{*}{ No. } & \multicolumn{2}{|c}{ Collagen (g.) } & \\
\cline { 2 - 3 } & P.M.F. & Rest & Whole Lung \\
\hline 1 & 9.9 & 11.4 & 21.3 \\
2 & 11.8 & 19.5 & 31.3 \\
3 & 11.1 & 10.6 & 21.7 \\
4 & 14.6 & 15.5 & 30.1 \\
5 & 14.7 & 10.8 & 25.5 \\
6 & 9.1 & 25.3 & 34.4 \\
7 & 10.4 & 8.1 & 18.5 \\
8 & 11.6 & 20.1 & 31.7 \\
9 & 7.0 & 13.5 & 20.5 \\
10 & 3.8 & 25.7 & 29.5 \\
11 & 4.86 & 16.7 & 21.5 \\
12 & - & 23.8 & - \\
13 & 1.94 & 13.42 & 15.4 \\
14 & 2.93 & 13.6 & 16.5 \\
15 & 2.1 & 16.5 & 18.6 \\
16 & 0.88 & 15.0 & 15.9 \\
17 & 0.85 & 9.6 & 10.5 \\
18 & 0.6 & 13.1 & 13.7 \\
\hline
\end{tabular}

lung, and for the whole lungs. (No collagen results could be obtained for the P.M.F. lesion of lung no. 12 because the material had been used for other work.)

Table 6 shows that the P.M.F. lesions tend to have a higher collagen percentage than the rest of the lungs, but this is not invariably so. If the lesions are small or if the men are younger, the collagen percentage in the P.M.F. lesions tends to be similar to that in the rest of the lungs. On an average, the dust-free tissue in the P.M.F. lesions contained $18.9 \%$ collagen 


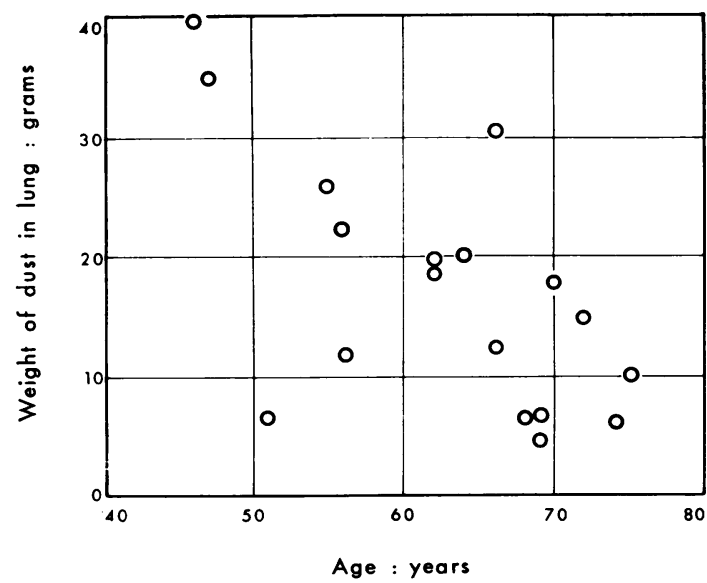

Fig. 1.-Lung dust and age at death for 18 cases of P.M.F.

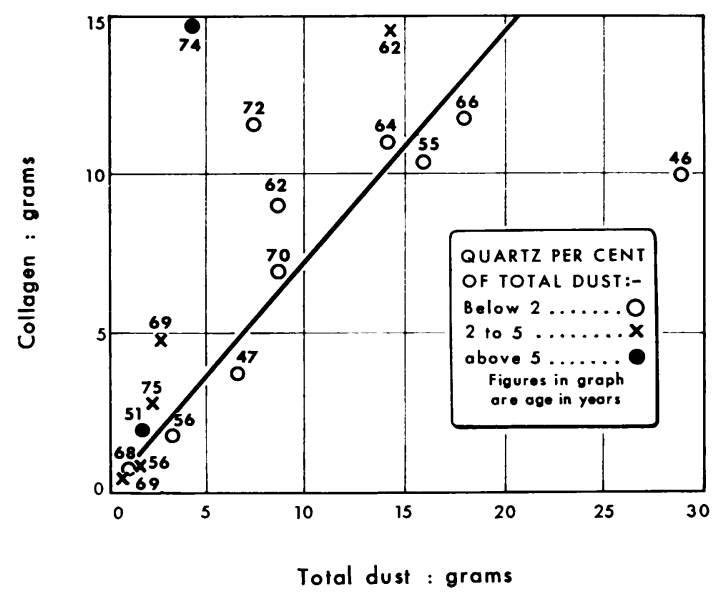

FIG. 2.-Collagen and total dust in massive lesions.

as against $16.7 \%$ for the rest of the lung. The value for the P.M.F. lesions is surprisingly low, and the difference is not statistically significant. Fig. 2 shows collagen plotted against total dust in the P.M.F. lesions. The effects of age and of the quartz content of the dust are marked. The younger the man and the lower the quartz percentage, the less collagen per unit of dust seems to be present in the lesions. On an average, as indicated by the line, the lesions contained slightly less than $1 \mathrm{~g}$. of collagen per $\mathrm{g}$. of dust.

Comparison of Lungs with P.M.F. and with Simple Pneumoconiosis.

Dust Composition.-It has been shown in the preceding section that the quartz percentage of the dust in the massive lesion was not higher than in the rest of the lung. But the silica theory of the origin
TABLE 6

PROGRESSIVE MASSIVE FIBROSIS: COLLAGEN AS PER CENT OF DUST-FREE LUNG IN SEPARATE PORTIONS AND IN THE WHOLE LUNGS

\begin{tabular}{c|c|c|c|c}
\hline \multirow{2}{*}{ No. } & \multirow{2}{*}{ Age } & \multicolumn{2}{|c}{ Collagen Per cent of Dust-free Lung Tissue in: } \\
\cline { 3 - 5 } & & P.M.F. & Rest & Whole Lung \\
\hline 1 & 46 & 12.2 & 18.9 & $15 \cdot 1$ \\
2 & 66 & 17.97 & 19.0 & 18.5 \\
3 & 64 & 18.5 & 15.2 & 16.7 \\
4 & 62 & 25.7 & 22.6 & 24.0 \\
5 & 74 & 22.4 & 18.5 & 20.5 \\
6 & 62 & 16.8 & 20.5 & 19.3 \\
7 & 55 & 25.8 & 16.8 & 20.8 \\
8 & 72 & 24.3 & 15.9 & 18.2 \\
9 & 70 & 22.4 & 16.7 & 18.3 \\
10 & 47 & 15.6 & 15.1 & 15.4 \\
11 & 58 & 20.0 & 15.0 & 15.9 \\
12 & 66 & - & 22.3 & - \\
13 & 56 & 15.8 & 10.3 & 10.8 \\
14 & 75 & 23.1 & 15.2 & 16.2 \\
15 & 51 & 16.7 & 15.8 & 15.9 \\
16 & 56 & 16.4 & 16.6 & 16.7 \\
17 & 68 & 14.4 & 12.9 & 13.0 \\
18 & 69 & 12.7 & 13.5 & 13.5 \\
\hline
\end{tabular}

of P.M.F. could also be supported if it were found that the dust in lungs with P.M.F. contains, on an average, more quartz than the dust in lungs with simple pneumoconiosis. Such an observation is more difficult to establish or to disprove because there is some variability in the composition of the lung dust of coal-workers. Fig. 3, which is based on earlier work, shows that, on an average, in South Wales the quartz percentage of the lung dust decreased with increasing amounts of total dust, whereas in Cumberland it increased. Our data so far have shown no significant difference in the quartz content of the lung dust when

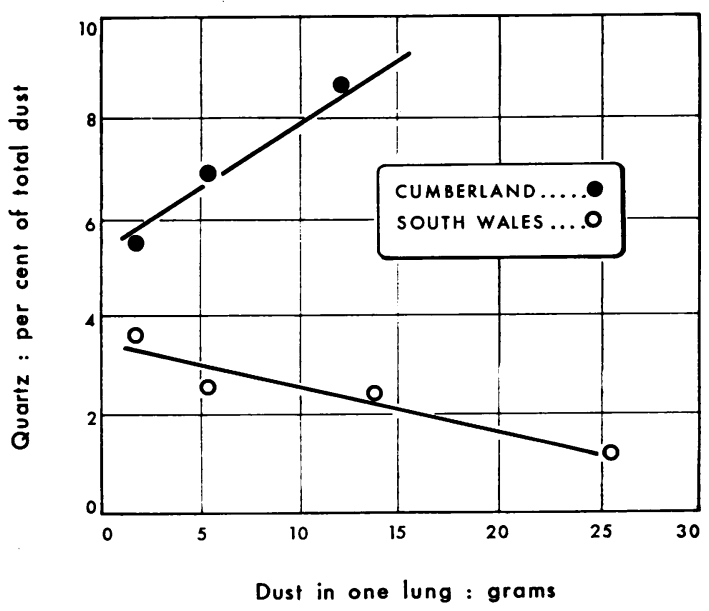

FIG. 3.-Relation between amount and composition of dust in lungs of coal-miners from Cumberland and South Wales. 
TABLE 7

PROGRESSIVE MASSIVE FIBROSIS (GROUP 1b): DUST AND COLLAGEN IN 14 LUNGS WITH P.M.F. FROM SOUTH WALES

\begin{tabular}{|c|c|c|c|c|c|c|c|}
\hline \multirow{2}{*}{ Code No.* } & \multirow{2}{*}{ Age } & \multirow{2}{*}{$\begin{array}{c}\text { Weight of Lung } \\
\text { (g.) }\end{array}$} & \multirow{2}{*}{$\begin{array}{c}\text { Weight of Dust } \\
\text { (g.) }\end{array}$} & \multirow{2}{*}{$\begin{array}{l}\text { Quartz } \\
\text { (\% dust) }\end{array}$} & \multirow{2}{*}{$\begin{array}{l}\text { Collagen } \\
(\mathrm{g} .)\end{array}$} & \multicolumn{2}{|c|}{$\%$ Dust-free Lung } \\
\hline & & & & & & Dust & Collagen \\
\hline $\begin{array}{r}59 \\
52 \\
78 \\
10 \\
9 \\
24 \\
81 \\
22 \\
99 \\
1 \\
96 \\
76 \\
97 \\
107\end{array}$ & $\begin{array}{l}54 \\
59 \\
59 \\
59 \\
65 \\
60 \\
74 \\
57 \\
63 \\
64 \\
64 \\
54 \\
71 \\
54\end{array}$ & $\begin{array}{l}215 \\
215 \\
200 \\
178 \\
189 \\
106 \\
166 \\
140 \\
121 \\
103 \\
151 \\
92 \\
136 \\
128\end{array}$ & $\begin{array}{l}67.6 \\
47.5 \\
43.7 \\
35.2 \\
26.7 \\
20.4 \\
16.1 \\
13.1 \\
11.1 \\
10.3 \\
9.8 \\
9.3 \\
7.0 \\
5.6\end{array}$ & $\begin{array}{r}1.0 \\
1.6 \\
1.6 \\
1.5 \\
2.6 \\
0.7 \\
10.5 \\
4.9 \\
0.4 \\
7.1 \\
2.9 \\
3.7 \\
4.8 \\
3.3\end{array}$ & $\begin{array}{l}22.6 \\
23.2 \\
24.6 \\
18.9 \\
27.8 \\
13.4 \\
25.7 \\
15.4 \\
21.5 \\
13.1 \\
24.9 \\
17 \cdot 1 \\
15.9 \\
20.5\end{array}$ & $\begin{array}{c}45 \cdot 7 \\
28 \cdot 2 \\
27.9 \\
24.7 \\
16.4 \\
23.8 \\
11 \cdot 0 \\
10 \cdot 2 \\
10 \cdot 1 \\
11 \cdot 1 \\
6.96 \\
11 \cdot 3 \\
5.4 \\
4 \cdot 50\end{array}$ & $\begin{array}{l}15.3 \\
13.85 \\
15.7 \\
13.2 \\
17.1 \\
15.6 \\
17.2 \\
12.1 \\
19.6 \\
14.1 \\
17.65 \\
20.7 \\
12.3 \\
16.7\end{array}$ \\
\hline
\end{tabular}

* Numbers as in Table 2 in King et al. (1956).

lungs from miners in South Wales and Scotland were compared, but Durham lungs had a significantly higher quartz content than those from South Wales and a significantly lower quartz content than Cumberland lungs (S.M.R.E., 1961). The lung dust of coal-miners from the Wigan area of Lancashire also had a high quartz percentage, similar to lung dust from Cumberland (Spink and Nagelschmidt, 1963). Furthermore, all our lungs were obtained from pathologists either because the men concerned died in hospital or because a coroner had ordered an autopsy, and in this way bias could be introduced. This bias can best be reduced by analysing only lungs of men who died in pit accidents. Our material so far includes 25 such cases, of which only two were lungs with P.M.F., so that no comparison of accident cases alone could be made. However, the composition of the lung dust of accident cases of simple pneumoconiosis showed the same range of values as the other lungs which we have analysed, and it appears unlikely that serious error is caused by such bias.

The quartz percentage of the lung dust in P.M.F. has been compared with that in simple pneumoconiosis. For this purpose we used the results for all P.M.F. lungs in groups $1 \mathrm{a}$ and $1 \mathrm{~b}$ and those for the simple pneumoconiosis lungs in groups $2 \mathrm{a}$ and $2 \mathrm{~b}$. (As the quartz determinations for group 1b lung dust had previously been made by a different technique, new residues were prepared and quartz analyses were made by the G-M counter technique of Gordon and Harris (1956). The results were on an average $25 \%$ lower than those reported previously for these lungs.) The total amounts of dust in these lungs ranged from 5.6 to $67.6 \mathrm{~g}$. (Table 7). The cases were divided into three groups according to their total dust content: 4.0 to $6.9 \mathrm{~g}$., 7.0 to $16.9 \mathrm{~g}$., and $17.0 \mathrm{~g}$. or more. Table 8 shows that the quartz percentage was always higher in the dust of the P.M.F. lungs
TABLE 8

PROGRESSIVE MASSIVE FIBROSIS AND SIMPLE PNEUMOCONIOSIS (GROUPS 2a AND b) AVERAGE QUARTZ PER CENTAGE OF LUNG DUST IN 32 CASES OF P.M.F. AND 58 CASES OF SIMPLE PNEUMOCONIOSIS

\begin{tabular}{|c|c|c|c|}
\hline & P.M.F. & $\begin{array}{c}\text { Simple } \\
\text { Pneumoconiosis }\end{array}$ & $\begin{array}{c}\text { Significance } \\
\text { Level of } \\
\text { Difference } \\
\text { P.M.F.-Simple }\end{array}$ \\
\hline $\begin{array}{l}\text { Over } 17 \text { g. of dust per lung } \\
\text { Mean quartz }(\%) \\
\text { Standard deviation } \\
\text { No. of lungs }\end{array}$ & $\begin{array}{l}1 \cdot 71 \\
0 \cdot 85 \\
15\end{array}$ & $\begin{array}{l}1.45 \\
0.91 \\
13\end{array}$ & Not significant \\
\hline $\begin{array}{l}7 \cdot 0-16.9 \mathrm{~g} . \text { of dust per lung } \\
\text { Mean quartz }(\%) \\
\text { Standard deviation } \\
\text { No. of lungs }\end{array}$ & $\begin{array}{l}4 \cdot 8 \\
3 \cdot 34 \\
11\end{array}$ & $\begin{array}{l}2 \cdot 1 \\
31\end{array}$ & 0.01 \\
\hline $\begin{array}{l}4 \cdot 0-6 \cdot 9 \mathrm{~g} . \text { of dust per lung } \\
\text { Mean quartz }(\%) \\
\text { Standard deviation } \\
\text { No. of lungs }\end{array}$ & $\begin{array}{l}4 \cdot 7 \\
2 \cdot 56 \\
6\end{array}$ & $\begin{array}{l}3 \cdot 15 \\
2 \cdot 27 \\
14\end{array}$ & Not significant \\
\hline $\begin{array}{l}\text { Whole series } \\
\text { Mean quartz (\%) } \\
\text { Standard deviation } \\
\text { No. of lungs }\end{array}$ & $\begin{array}{l}3 \cdot 3 \\
2 \cdot 71 \\
32\end{array}$ & $\begin{array}{c}2 \cdot 2 \\
1.93 \\
58\end{array}$ & 0.05 \\
\hline $\begin{array}{l}\text { Whole series omitting Durh } \\
\text { Mean quartz }(\%) \\
\text { Standard deviation } \\
\text { No. of lungs }\end{array}$ & $\int_{23}^{2 \cdot 9}$ & $\frac{2 \cdot 1}{52}$ & Not significant \\
\hline
\end{tabular}

than in the lungs with simple pneumoconiosis. But the differences were small and not significant in the high and low dust groups. For the three groups together the difference, $3 \cdot 3$ as against $2 \cdot 2 \%$, was significant at the $5 \%$ level, but when the Durham lungs were omitted it was not significant $(2.9$ as against $2 \cdot 1 \%$ ). This suggests that the small differences observed could well be due to sampling.

Collagen Content.-The average collagen content of 17 of the 18 P.M.F. lungs in group 1a (Table 1) was computed from the separate analyses of the P.M.F. lesions and of the rest of the lung and expressed as grams collagen per lung (Table 5) and also as collagen per cent of dust-free lung tissue 
(Table 6). Similar data are given for the 14 P.M.F. lungs in group $1 \mathrm{~b}$ in Table 7 . Collagen analyses were also made on 27 lungs with simple pneumoconiosis selected to match the P.M.F. lungs as well as possible for total dust, quartz percentage, age, and coalfield (group 2c). The results are given in Table 9, arranged in order of decreasing amount of dust in the lungs. A comparison of the results for collagen as grams per lung and as per cent dust-free tissue shows slightly but not significantly higher average values for the P.M.F. lungs (Table 10).

The collagen content of the lung is likely to increase with age (Briscoe, Loring, and McClement, 1959), amount of dust, and, perhaps, with the quartz percentage of the dust. It might be possible to establish these relations quantitatively by statistical analysis. However, there is great variability of the collagen values observed in this small series and such an analysis will not be worthwhile until many more pneumoconiotic lungs and an adequate number of controls have been studied. In the meantime the following approach was made. For every lung, collagen and total dust were expressed as per cent dust-free tissue. From the regression line in Fig. 2 in the paper by Briscoe et al. (1959) a collagen value (as per cent dried lung) appropriate to age was taken and subtracted from the observed collagen, leaving extra collagen as per cent dust-free lung. This value

TABLE 9

SIMPLE PNEUMOCONIOSIS (GROUP 2c): DUST AND COLLAGEN IN 27 LUNGS WITH SIMPLE PNEUMOCONIOSIS FROM DIFFERENT COALFIELDS

\begin{tabular}{|c|c|c|c|c|c|c|c|}
\hline \multirow{2}{*}{ Code No.* } & \multirow{2}{*}{ Age } & \multirow{2}{*}{$\begin{array}{c}\text { Weight of Lung } \\
\text { (g.) }\end{array}$} & \multirow{2}{*}{$\begin{array}{l}\text { Weight of Dust } \\
\text { (g.) }\end{array}$} & \multirow{2}{*}{$\begin{array}{l}\text { Quartz } \\
\text { (\% dust) }\end{array}$} & \multirow{2}{*}{$\begin{array}{c}\text { Collagen } \\
\text { (g.) }\end{array}$} & \multicolumn{2}{|c|}{$\%$ Dust-f ree Lung } \\
\hline & & & & & & Dust & Collagen \\
\hline $\begin{array}{l}45 \\
\text { CD6 } \\
44\end{array}$ & $\begin{array}{l}53 \\
58 \\
58\end{array}$ & $\begin{array}{l}241 \\
149 \\
222\end{array}$ & $\begin{array}{l}44 \cdot 1 \\
35 \cdot 3 \\
33 \cdot 5\end{array}$ & $\begin{array}{l}1.4 \\
0.8 \\
1.7\end{array}$ & $\begin{array}{l}24 \cdot 1 \\
25 \cdot 3 \\
22 \cdot 5\end{array}$ & $\begin{array}{l}22 \cdot 5 \\
31 \cdot 2 \\
17 \cdot 8\end{array}$ & $\begin{array}{l}12 \cdot 2 \\
22 \cdot 2 \\
11 \cdot 9\end{array}$ \\
\hline $\begin{array}{l}37 \\
\text { CD16 } \\
\text { SB16 }\end{array}$ & $\begin{array}{l}54 \\
62 \\
58\end{array}$ & $\begin{array}{l}172 \\
147 \\
140\end{array}$ & $\begin{array}{l}31 \cdot 0 \\
20 \cdot 2 \\
18 \cdot 1\end{array}$ & $\begin{array}{l}0.7 \\
0.8 \\
3.4\end{array}$ & $\begin{array}{l}15 \cdot 5 \\
24 \cdot 3 \\
21 \cdot 0\end{array}$ & $\begin{array}{l}22.1 \\
15.9 \\
14.9\end{array}$ & $\begin{array}{l}11 \cdot 1 \\
19 \cdot 1 \\
17 \cdot 2\end{array}$ \\
\hline $\begin{array}{l}42 \\
34 \\
33\end{array}$ & $\begin{array}{l}70 \\
58 \\
58\end{array}$ & $\begin{array}{l}123 \\
159 \\
147\end{array}$ & $\begin{array}{l}16 \cdot 2 \\
14 \cdot 1 \\
12 \cdot 8\end{array}$ & $\begin{array}{r}10 \cdot 5 \\
3 \cdot 0 \\
2 \cdot 7\end{array}$ & $\begin{array}{l}23.0 \\
13.0 \\
14.9\end{array}$ & $\begin{array}{r}15 \cdot 2 \\
9.8 \\
9.6\end{array}$ & $\begin{array}{r}21 \cdot 5 \\
9 \cdot 0 \\
11 \cdot 1\end{array}$ \\
\hline $\begin{array}{l}\text { SB92 } \\
\text { SB15 } \\
\text { SB40 }\end{array}$ & $\begin{array}{l}60 \\
65 \\
68\end{array}$ & $\begin{array}{l}158 \\
151 \\
138\end{array}$ & $\begin{array}{r}12.0 \\
11.0 \\
9.2\end{array}$ & $\begin{array}{l}5 \cdot 3 \\
0 \cdot 5 \\
0 \cdot 4\end{array}$ & $\begin{array}{l}21 \cdot 5 \\
24 \cdot 3 \\
21 \cdot 0\end{array}$ & $\begin{array}{l}8 \cdot 2 \\
7 \cdot 9 \\
7 \cdot 2\end{array}$ & $\begin{array}{l}14 \cdot 8 \\
17 \cdot 4 \\
16 \cdot 3\end{array}$ \\
\hline $\begin{array}{l}\text { SB106 } \\
\text { SB19 } \\
\text { SB8 }\end{array}$ & $\begin{array}{l}78 \\
58 \\
61\end{array}$ & $\begin{array}{l}154 \\
174 \\
145\end{array}$ & $\begin{array}{l}9 \cdot 7 \\
8 \cdot 7 \\
8 \cdot 3\end{array}$ & $\begin{array}{l}2 \cdot 8 \\
1 \cdot 7 \\
0 \cdot 5\end{array}$ & $\begin{array}{l}17 \cdot 7 \\
27 \cdot 3 \\
21 \cdot 7\end{array}$ & $\begin{array}{l}6 \cdot 7 \\
5 \cdot 3 \\
5 \cdot 7\end{array}$ & $\begin{array}{l}12 \cdot 3 \\
16 \cdot 7 \\
14 \cdot 8\end{array}$ \\
\hline $\begin{array}{l}\text { SB28 } \\
\text { SB38 } \\
\text { CD13 }\end{array}$ & $\begin{array}{l}69 \\
69 \\
52\end{array}$ & $\begin{array}{l}142 \\
110 \\
110\end{array}$ & $\begin{array}{l}7 \cdot 8 \\
7 \cdot 8 \\
6 \cdot 6\end{array}$ & $\begin{array}{l}3 \cdot 4 \\
2 \cdot 1 \\
5 \cdot 0\end{array}$ & $\begin{array}{l}17 \cdot 2 \\
20 \cdot 4 \\
12 \cdot 4\end{array}$ & $\begin{array}{l}5 \cdot 8 \\
7 \cdot 6 \\
6 \cdot 4\end{array}$ & $\begin{array}{l}12.8 \\
19.9 \\
12.0\end{array}$ \\
\hline $\begin{array}{l}23 \\
\text { CD17 } \\
\text { CD10 }\end{array}$ & $\begin{array}{l}57 \\
62 \\
60\end{array}$ & $\begin{array}{l}126 \\
105 \\
146\end{array}$ & $\begin{array}{l}5 \cdot 7 \\
5 \cdot 0 \\
4 \cdot 5\end{array}$ & $\begin{array}{l}4 \cdot 8 \\
1 \cdot 1 \\
8 \cdot 0\end{array}$ & $\begin{array}{l}13.9 \\
16.3 \\
20.4\end{array}$ & $\begin{array}{l}4 \cdot 7 \\
5 \cdot 0 \\
3 \cdot 2\end{array}$ & $\begin{array}{l}11 \cdot 5 \\
16 \cdot 3 \\
14 \cdot 4\end{array}$ \\
\hline $\begin{array}{l}\text { SB96 } \\
\text { CD2 } \\
\text { CD5 }\end{array}$ & $\begin{array}{l}66 \\
61 \\
65\end{array}$ & $\begin{array}{l}138 \\
104 \\
175\end{array}$ & $\begin{array}{l}4 \cdot 4 \\
4 \cdot 1 \\
4 \cdot 0\end{array}$ & $\begin{array}{l}2 \cdot 3 \\
9 \cdot 4 \\
2 \cdot 0\end{array}$ & $\begin{array}{l}19 \cdot 3 \\
17 \cdot 2 \\
31 \cdot 6\end{array}$ & $\begin{array}{l}3 \cdot 6 \\
4 \cdot 1 \\
2 \cdot 4\end{array}$ & $\begin{array}{l}14 \cdot 5 \\
17 \cdot 1 \\
18 \cdot 5\end{array}$ \\
\hline $\begin{array}{l}48815 / 58 \\
59 / 893 \\
\text { SB100 }\end{array}$ & $\begin{array}{l}36 \\
63 \\
51\end{array}$ & $\begin{array}{r}98 \\
99 \\
127 \\
\end{array}$ & $\begin{array}{l}2 \cdot 7 \\
2 \cdot 6 \\
2 \cdot 4\end{array}$ & $\begin{array}{l}2 \cdot 7 \\
4 \cdot 0 \\
3 \cdot 0 \\
\end{array}$ & $\begin{array}{l}12 \cdot 2 \\
14 \cdot 0 \\
13 \cdot 3\end{array}$ & $\begin{array}{l}2 \cdot 8 \\
2 \cdot 7 \\
1.9\end{array}$ & $\begin{array}{l}13 \cdot 0 \\
14 \cdot 5 \\
10.7\end{array}$ \\
\hline
\end{tabular}

*Plain numbers refer to Rivers et al. (1960), Table 2.

TABLE 10

COMPARISON OF PROGRESSIVE MASSIVE FIBROSIS AND SIMPLE PNEUMOCONIOSIS: AVERAGE COLLAGEN AS GRAMS PER LUNG AND AS PER CENT OF DUST-FREE TISSUE IN P.M.F. AND IN SIMPLE PNEUMOCONIOSIS, GROUPED ACCORDING TO AMOUNT OF DUST IN LUNGS

\begin{tabular}{|c|c|c|c|c|c|c|c|c|c|c|}
\hline \multirow{3}{*}{ Dust in Lungs (g.) } & \multicolumn{5}{|c|}{ P.M.F. } & \multicolumn{5}{|c|}{ Simple Pneumoconiosis } \\
\hline & \multirow{2}{*}{$\begin{array}{l}\text { No. of } \\
\text { Lungs }\end{array}$} & \multicolumn{2}{|c|}{ Collagen (g.) } & \multicolumn{2}{|c|}{ Collagen (\%) } & \multirow{2}{*}{$\begin{array}{l}\text { No. of } \\
\text { Lungs }\end{array}$} & \multicolumn{2}{|c|}{ Collagen (g.) } & \multicolumn{2}{|c|}{ Collagen $(\%)$} \\
\hline & & Mean & Range & Mean & Range & & Mean & Range & Mean & Range \\
\hline $\begin{array}{l}\text { Over } 20 \\
10-19.9 \\
5-9 \cdot 9 \\
2 \cdot 4-4.9 \\
\text { All }\end{array}$ & $\begin{array}{r}12 \\
10 \\
8 \\
1 \\
31\end{array}$ & $\begin{array}{l}22 \cdot 2 \\
22 \cdot 5 \\
19 \cdot 3 \\
13 \cdot 7\end{array}$ & $\begin{array}{c}13-30 \\
12-24 \\
11-25 \\
-\end{array}$ & $\begin{array}{l}15.7 \\
17.6 \\
16.6 \\
13.5\end{array}$ & $\begin{array}{c}11-21 \\
12-24 \\
12-21 \\
-\end{array}$ & $\begin{array}{r}5 \\
6 \\
9 \\
7 \\
27\end{array}$ & $\begin{array}{l}22.3 \\
19.6 \\
18.6 \\
18.3\end{array}$ & $\begin{array}{l}15-24 \\
13-24 \\
12-27 \\
12-31\end{array}$ & $\begin{array}{l}15.3 \\
15.2 \\
14.7 \\
14.7\end{array}$ & $\begin{array}{r}11-22 \\
9-22 \\
12-20 \\
11-18\end{array}$ \\
\hline
\end{tabular}


divided by the total dust (also as per cent dust-free lung) gave grams of extra collagen per gram of dust. This calculation could only be made for 41 out of 58 lungs. In seven P.M.F. and 10 simple pneumoconiosis lungs the collagen values observed were lower than those assumed to be normal for age, so that there was no extra collagen.

Mean values and ranges for extra collagen per unit dust for 27 P.M.F. and 17 simple pneumoconiosis lungs are shown in Table 11. The results for both groups were very similar; the amount of extra

TABLE 11

AVERAGE EXTRA COLLAGEN (IN g. PER g. DUST) IN 41 LUNGS OF COAL-WORKERS

\begin{tabular}{|c|c|c|c|}
\hline & P.M.F. & $\begin{array}{c}\text { Simple } \\
\text { Pneumoconiosis }\end{array}$ & All \\
\hline $\begin{array}{l}\text { Mean value } \\
\text { Range } \\
\text { No. of lungs }\end{array}$ & $\begin{array}{c}0 \cdot 30 \\
0 \cdot 1-1 \cdot 1 \\
24\end{array}$ & $\begin{array}{c}0.46 \\
0 \cdot 1-0 \cdot 8^{*} \\
17\end{array}$ & $\begin{array}{r}0 \cdot 37 \\
41\end{array}$ \\
\hline
\end{tabular}

*With one exceptionally high value of $\mathbf{1 . 8}$.

collagen per gram of coal-workers' lung dust appears to be of the order of $0.4 \mathrm{~g}$.

A break-down of the values for the 41 lungs according to the quartz percentage of the lung dust showed a trend for extra collagen production to increase slightly as the quartz percentage increased, but the scatter of the data was large (see top of Fig. 4). However, similar calculations for five silicotic

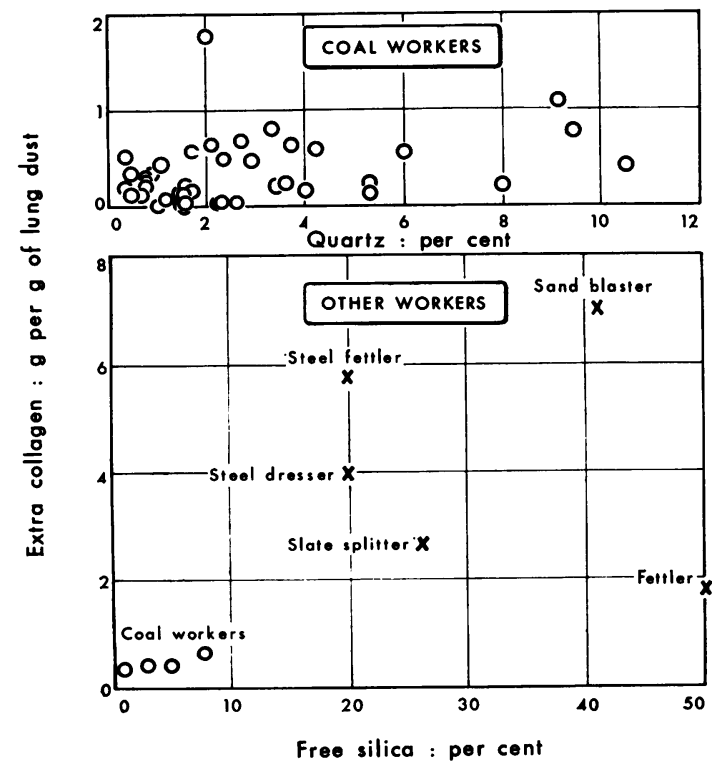

Fig. 4.-Extra collagen (g. collagen per g. dust, corrected for age) as function of quartz content of lung dust. lungs for which lung dust and collagen data were obtained showed the values for extra collagen per unit dust to be about 10 times higher. This is illustrated in Fig. 4 in which extra colllagen is plotted against the quartz (plus cristobalite) percentage of the lung dust. The points for coalworkers correspond to the mean values for quartz percentages of the lung dust of below 2.0, $2 \cdot 1$ to $4 \cdot 0$, $4 \cdot 1$ to $6 \cdot 0$, and $6 \cdot 1$ to 10.5 , and the number of the lungs in these four groups were 21,12 , four, and four, respectively. The period from the beginning of dust exposure until death for the five silicotic lungs ranged from 20 to 40 years.

These results are in agreement with general knowledge about the power of quartz-rich dusts to produce collagen. The effect of low proportions of quartz of the order of 1 to $5 \%$ of the lung dust is probably slight and the present evidence is compatible with this view.

Pathology.-The relatively small collagen content of the P.M.F. lesion appears to be at variance with the naked-eye and histological observations of pathologists. Study of representative histological sections of the massive lesions revealed certain features which may to some extent account for this discrepancy. Sections stained with haematoxylin and eosin show the P.M.F. mass to contain numerous bundles of eosinophilic fibres with the characteristic appearances of collagen, although there is an almost complete absence of nuclei. Interspersed amongst these bundles are other fibres of similar morphology which are only faintly eosinophilic. Indeed, there is a whole range of staining reaction extending from fibres which are frankly eosinophilic to others which have hardly taken up any stain. There is variable spacing between the fibres, and the coal dust, mainly free, is distributed throughout the spaces; dust-laden macrophages are seen in the larger spaces. Sections stained for reticulin show the eosinophilic fibres to have the characteristic yellowish-brown colour of collagen but the paler eosinophilic fibres are represented by a dense reticulin network. Sections stained by the Weigert and van Gieson method again show the characteristic red staining of the well-defined collagen fibres, but the other fibres take up little, if any, of the red stain. It is conceivable that the chemical determination of the hydroxyproline content of the P.M.F. lesion represents mainly the eosinophilic fibres whereas in the paler staining fibres there may have occurred chemical changes resulting in a lower hydroxyproline content. The P.M.F. lesions did not appear to contain any material giving a positive reaction with the periodic-acidSchiff staining technique. Other characteristic features of the P.M.F. lesion have already been well described by Gough (1940), Fletcher and Gough 


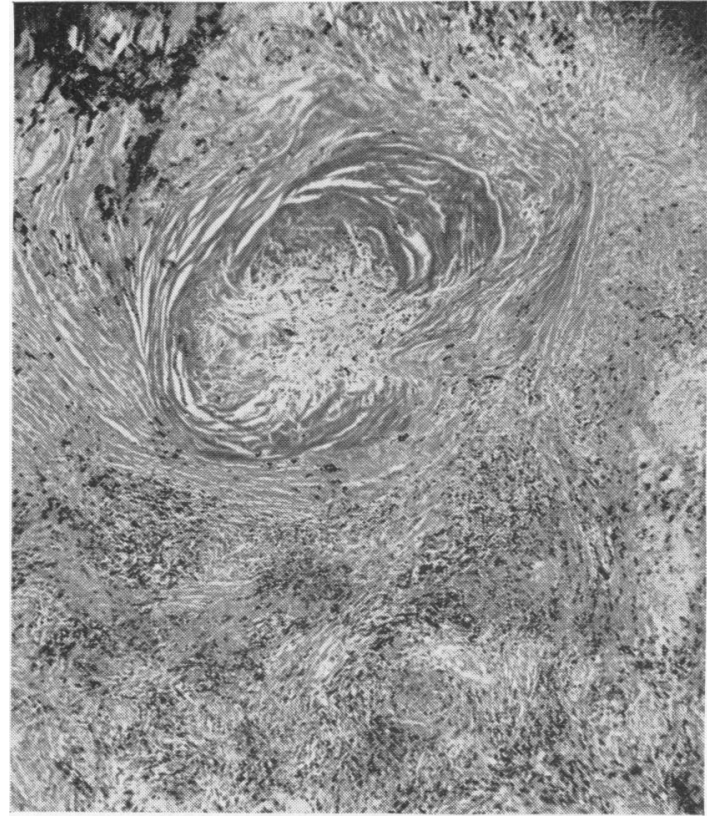

FIG. 5.-Characteristic whorled silicotic lesion within an area of P.M.F. from case 15 (H. and E. $\times 48)$.

(1950), Heppleston (1951), and Wells (1954). These authors clearly differentiate the features of the P.M.F. lesion from those of the silicotic lesion. The contrast in the features of the two lesions is well exemplified by the presence of a silicotic nodule embedded in a mass of P.M.F. tissue in case no. 15 (Fig. 5) where the dust of the P.M.F. lesion contained $8.5 \%$ of quartz. This strongly suggests that where a sufficient concentration of silica is present a characteristic silicotic lesion develops; if P.M.F. were a modified silicotic reaction it is unlikely that a classical silicotic lesion would be found within a P.M.F. lesion.

TABLE 12

DUST ACCUMULATION RATE (g./YEAR IN ONE LUNG) IN P.M.F. AND SIMPLE PNEUMOCONIOSIS

\begin{tabular}{|c|c|c|c|}
\hline $\begin{array}{l}\text { Total Dust in } \\
\text { One Lung }\end{array}$ & P.M.F. & $\begin{array}{c}\text { Simple } \\
\text { Pneumoconiosis }\end{array}$ & $\begin{array}{c}\text { Significance of } \\
\text { Difference }\end{array}$ \\
\hline $\begin{array}{l}\text { Over } 20 \mathrm{~g} . \\
\text { Mean } \\
\text { Range } \\
\text { No. of lungs }\end{array}$ & $\begin{array}{c}0.99 \\
0.45-2 \cdot 1 \\
12\end{array}$ & $\begin{array}{c}0.99 \\
0.5-1.9 \\
9\end{array}$ & Not significant \\
\hline $\begin{array}{l}10 \text { to } 19 \mathrm{~g} . \\
\text { Mean } \\
\text { Range } \\
\text { No. of lungs }\end{array}$ & $\begin{array}{c}0 \cdot 42 \\
0 \cdot 2-0 \cdot 8 \\
10\end{array}$ & $\begin{array}{c}0 \cdot 52 \\
0 \cdot 3-0 \cdot 7 * \\
23\end{array}$ & Not significant \\
\hline $\begin{array}{l}4.5 \text { to } 9.9 \mathrm{~g} . \\
\text { Mean } \\
\text { Range } \\
\text { No. of lungs }\end{array}$ & $\begin{array}{c}0 \cdot 22 \\
0 \cdot 1-0 \cdot 4 \\
9\end{array}$ & $\begin{array}{c}0 \cdot 20 \\
0 \cdot 1-0 \cdot 3 \\
19\end{array}$ & Not significant \\
\hline
\end{tabular}

*With one exceptionally high value of $1.7 \mathrm{~g}$./year.
TABLE 13

MEAN AGES AT DEATH OF MEN WITH P.M.F. AND SIMPLE PNEUMOCONIOSIS: DIFFERENT AMOUNTS OF TOTAL DUST IN THE LUNGS

\begin{tabular}{|c|c|c|c|}
\hline $\begin{array}{l}\text { Total Dust in } \\
\text { One Lung }\end{array}$ & P.M.F. & $\begin{array}{c}\text { Simple } \\
\text { Pneumoconiosis }\end{array}$ & $\begin{array}{l}\text { Simple } \\
\text { Pneumoconiosis: } \\
\text { Accidents } \\
\text { Omitted }\end{array}$ \\
\hline $\begin{array}{l}\text { Over } 20 \mathrm{~g} . \\
\text { Mean age } \\
\text { Range } \\
\text { No. of lungs }\end{array}$ & $\begin{array}{c}57 \cdot 2 \\
46-65 \\
12\end{array}$ & $\begin{array}{c}55 \cdot 4 \\
37-68 \\
9\end{array}$ & \\
\hline $\begin{array}{l}10 \text { to } 19.9 \mathrm{~g} . \\
\text { Mean age } \\
\text { Range } \\
\text { No. of lungs }\end{array}$ & $\begin{array}{c}64 \cdot 7 \\
56-75 \\
10\end{array}$ & $\begin{array}{c}49 \cdot 3 \\
35-81 \\
23\end{array}$ & $\begin{array}{c}53 \cdot 5 \\
38-81 \\
13\end{array}$ \\
\hline $\begin{array}{l}4.5 \text { to } 9.9 \mathrm{~g} . \\
\text { Mean age } \\
\text { Range } \\
\text { No. of lungs }\end{array}$ & $\begin{array}{c}63 \cdot 8 \\
51-74 \\
9\end{array}$ & $\begin{array}{c}60 \cdot 2 \\
33-78 \\
19\end{array}$ & \\
\hline
\end{tabular}

TABLE 14

MEAN AGES AT DEATH OF MEN WITH P.M.F. AND SIMPLE PNEUMOCONIOSIS: DIFFERENT DUST ACCUMULATION RATES

\begin{tabular}{|c|c|c|c|}
\hline $\begin{array}{c}\text { Dust } \\
\text { Accumulation } \\
\text { Rate } \\
\text { (g./year) }\end{array}$ & P.M.F. & $\begin{array}{c}\text { Simple } \\
\text { Pneumoconiosis }\end{array}$ & $\begin{array}{c}\text { Simple } \\
\text { Pneumoconiosis : } \\
\text { Accidents } \\
\text { Omitted }\end{array}$ \\
\hline $\begin{array}{l}\text { Over } 1 \mathrm{~g} . \\
\text { Mean age } \\
\text { Range } \\
\text { No. of lungs }\end{array}$ & $\begin{array}{c}53 \cdot 3 \\
46-59 \\
6\end{array}$ & $\begin{array}{c}45 \cdot 5 \\
35-57 \\
4\end{array}$ & $\begin{array}{c}49 \\
37-57 \\
3\end{array}$ \\
\hline $\begin{array}{c}0.5 \text { to } 0.99 \mathrm{~g} . \\
\text { Mean age } \\
\text { Range } \\
\text { No. of lungs }\end{array}$ & $\begin{array}{c}61 \cdot 2 \\
56-65 \\
7\end{array}$ & $\begin{array}{c}53 \cdot 5 \\
36-68 \\
16\end{array}$ & $\begin{array}{c}55 \cdot 4 \\
38-62 \\
10\end{array}$ \\
\hline $\begin{array}{l}0.25 \text { to } 0.49 \mathrm{~g} . \\
\text { Mean age } \\
\text { Range } \\
\text { No. of lungs }\end{array}$ & $\begin{array}{c}63 \cdot 2 \\
51-72 \\
10\end{array}$ & $\begin{array}{c}55 \cdot 1 \\
33-81 \\
17\end{array}$ & $\begin{array}{c}59 \\
33-81 \\
12\end{array}$ \\
\hline $\begin{array}{l}0.1 \text { to } 0.245 \mathrm{~g} . \\
\text { Mean age } \\
\text { Range } \\
\text { No. of lungs }\end{array}$ & $\begin{array}{c}66 \cdot 1 \\
54-75 \\
8\end{array}$ & $\begin{array}{c}63 \cdot 6 \\
56-78 \\
16\end{array}$ & \\
\hline
\end{tabular}

Dust Accumulation Rates and Ages at Death.When the amount of dust in one lung is divided by the number of years of dust exposure a dust accumulation rate (g. of dust in one lung per year) is obtained. This rate is based on the not necessarily correct assumption that dust accumulation is uniform; it is, however, the simplest assumption and may serve to compare the rates in simple pneumoconiosis with those in P.M.F. The length of dust exposure was known for all except one of the 32 P.M.F. lungs and also for 52 of the 58 lungs with simple pneumoconiosis. The rates were compared at three levels of total dust in one lung, i.e. over $20 \mathrm{~g}$., 10 to $19.9 \mathrm{~g}$., and 4.5 to $9.9 \mathrm{~g}$. The results, given in Table 12 , show practically no difference in the dust accumulation rate between simple pneumoconiosis and P.M.F.

Table 13 shows the corresponding ages at death. In this series men with simple pneumoconiosis did 
not reach higher average ages than men with P.M.F., even if all accident cases were omitted from the calculation. A similar result was obtained when average ages for various levels of dust accumulation rates were compared, again omitting the accident cases (Table 14). High dust levels or accumulation rates seem to be associated with death at a younger age.

\section{Comment}

What bearing have these results on the origin of P.M.F.? According to the silica theory, the massive lesions are caused by quartz, presumably by confluence of silicotic nodules. Such nodules are relatively rare in coal-workers' lungs but a few may be found by diligent search.

It is well known from animal experiments that injected or inhaled quartz moves faster than coal to the lymph glands (Nagelschmidt, Nelson, King, Attygalle and Yoganathan, 1957; Klosterkötter and Bünemann, 1961), and the dust isolated by us from a few lymph glands of coal-workers with simple pneumoconiosis showed a considerably higher quartz content than the corresponding lung dust. In a similar way foci of higher quartz content than in the average lung dust could form in certain parts of the lungs, and it would be these foci which tended to form massive lesions. Figure 5 from case 15 might be thought to illustrate such a process. The lung dust in this case had the rather high quartz content of $8.5 \%$.

But if this were generally the case, one would find higher quartz percentages in the lung dust of the massive lesions than in the dust of the rest of the lung, especially in small lesions. Our data (Table 3) show clearly that this is not the case, and this to us is strong evidence against the silica theory of P.M.F. Furthermore, P.M.F. has been found in the almost complete absence of quartz in the lung dust of carbon electrode grinders (Watson, Black, Doig, and Nagelschmidt, 1959), carbon black workers (Miller and Ramsden, 1961) and in kaolin, talc, and mica lungs (Nagelschmidt, 1960).

The data comparing the quartz percentages of dust in lungs with P.M.F. and with simple pneumoconiosis at similar total dust contents (Table 8) give perhaps some slight support to the silica theory but the evidence is very weak. The differences in quartz content are so small, even if they are statistically significant for the medium dust group, that they cannot in our opinion reverse the other evidence.

The analyses do not throw any direct light on the "tuberculosis" theory of P.M.F. A condition closely similar to P.M.F. has been produced experimentally in animals with coal dust and tuberculosis in the laboratory of one of us (E.J.K.) (e.g. Zaidi, Harrison,
King, and Mitchison, 1955; Byers and King, 1961), and even with coal dust almost free of quartz and silicates (Attygalle, Harrison, King and Mohanty, 1954), but this does not necessarily prove that the aetiology is the same in human lungs, though the presumptive evidence may be considered strong.

Equally, although our data cannot prove or disprove the "total dust" hypothesis, they are compatible with it. They only show that P.M.F. can occur in the presence of very little dust, but the attack rate of P.M.F. may very well increase steeply with $x$-ray category above 1 or with higher dust concentrations in the lungs, as demonstrated by Cochrane (1962)

The collagen analyses have given the very unexpected result that there is far less collagen in the P.M.F. lesions than one would have thought on the basis of previous histopathological evidence. In fact, the collagen percentages of the dust-free tissue are hardly different for lungs with P.M.F. or lungs with simple pneumoconiosis (Table 10) and, in P.M.F. lungs, for the massive lesions as compared with the rest of the lungs (Table 6).

It has been suggested that the massive lesions are the result of collapse of part of the lung. This is unlikely. A few rough measurements have shown that in formalin-fixed lungs $1 \mathrm{~cm}^{3}$. of a massive lesion contains ca. $300 \mathrm{mg}$. of dried matter as against $80 \mathrm{mg}$. for spongy dust-free lung tissue. Using these figures for lung no. 1 in Table 1, the P.M.F. lesion which weighed $110 \mathrm{~g}$. would have occupied a volume of $365 \mathrm{ml}$., and the rest of the lung which contained $60 \mathrm{~g}$. dust-free tissue a volume of $750 \mathrm{ml}$., giving a total of $1,115 \mathrm{ml}$. If the P.M.F. lesion of $365 \mathrm{ml}$. had contained normal dust-free tissue, this would have weighed $29 \mathrm{~g}$. In fact the dust-free tissue weight was $81 \mathrm{~g}$., leaving an extra weight of $52 \mathrm{~g}$. of material of similar collagen content to lung tissue. This would have corresponded to $650 \mathrm{ml}$. of normal lung tissue if it had in fact been such. The Gough section does not suggest that the original lung could have been so much larger and the massive lesion must be described as due to infilling or consolidation rather than to collapse.

This work has emphasized the lack of knowledge of the biochemical composition of the massive lesions or, for that matter, of normal lung tissue. Collagen and lipids (extractable by alcohol-ether) account for less than half of the organic material in lungs or massive lesions. It has been suggested that mucopolysaccharides and globulins are major constituents. They need to be studied and the results may contribute to an explanation of the origin of P.M.F. More work on normal lungs and the effect of age on their composition is also needed. We have used the data of Briscoe et al. (1959), who determined hydroxyproline and found that the collagen (plus 
elastin) content of a random selection of lungs increased significantly with age. They had used peripheral areas of the left upper lobes. Similar work by Pierce and Hocott (1960), using a different (gravimetric) technique on right middle lobes, suggests a significant increase in elastin but no increase in collagen content with age. Unfortunately, these authors did not carry out hydroxyproline determinations on their collagen fractions, so that the results are not strictly comparable with those of Briscoe et al. but the need for more information is obvious.

The dust-free lung tissue weights used throughout in our work are probably far too high because they include the dried weight from blood which had remained in the capillaries. The extrapolated average dried weight of a single lung without dust was of the order of $100 \mathrm{~g}$. in our material. But, according to Hieronymi (1961), the average dried weight of right lungs of adult men carefully freed from blood is only of the order of $40 \mathrm{~g}$. When collagen is expressed as per cent dried tissue it will be the lower the more blood had remained in the tissues. It is possible that much of the variability of collagen content with age observed by Briscoe et al. (1959) and by Pierce and Hocott (1960) was also due to the presence of variable amounts of blood in their lung samples.

Our thanks are due to Professor D. F. Cappell, Dr. J. E. Ennis, Professor J. Gough, Dr. G. S. Graham, Dr. W. Stewart, and Dr. A. J. Watson for providing lungs, to
Dr. J. Black, Dr. J. Egan, Dr. T. H. Jenkins, and Dr. T. D. Spencer for industrial histories, and to many of our colleagues for advice and technical help.

Two of us (E.J.K. and W.T.) are grateful to the Medical Research Council and the National Coal Board for financial assistance.

\section{REFERENCES}

Attygalle, D., Harrison, C. V., King, E. J., and Mohanty, G. P. (1954) Brit. J. industr. Med., 11, 245.

Briscoe, A. M., Loring, W. E., and McClement, J. H. (1959). Proc. Soc. exp. Biol. (N.Y.), 102, 71 .

Byers, P. D., and King, E. J. (1961). J. Path. Bact., 81, 123.

Cochrane, A. L. (1960). In Industrial Pulmonary Diseases: A Symposium held at the Postgraduate Medical School of London, 1957 and 1958, ed. E. J. King and C. M. Fletcher, p. 221. Churchill, London.

(1962). Brit. J. industr. Med., 19, 52.

Fletcher, C. M., and Gough, J. (1950). Brit. med. Bull., 7, 42.

Gordon, R. L., and Harris, G. W. (1956). Safety in Mines Research Establishment Research Report No. 138. H.M.S.O., London.

Gough, J. (1940). J. Path. Bact., 51, 277.

Heppleston, A. G. (1951). A.M.A. Arch. industr. Hyg., 4, 270

Hieronymi, G. (1961). Ergebn. allg. Path. path. Anat., 41, 1 (see Fig. 11 on p. 30).

King, E. J., Maguire, B. A., and Nagelschmidt, G. (1956). Brit. J. industr. Med., 13, 9.

Klosterkötter, W and Bünemann, G. (1961). In Inhaled Particles and Vapours. Edited by C. N. Davies, p. 327. Pergamon Press, London

Miller, A. A and Ramsden, F. (1961), Brit. J. industr. Med., 18, 103. Nagelschmidt, G. (1960). Ibid., 17, 247.

, Nelson, E. S., King, E. J., Attygalle, D., and Yoganathan, M. (1957). A.M.A. Arch. industr. Hlth., 16, 188.

Neuman, R. E., and Logan, M. A. (1950). J. biol. Chem., 184, 299.

Pierce, J. A., and Hocott, J. B. (1960). J. clin. Invest., 39, 8.

Rivers, D., Wise, M. E., King, E. J., Nagelschmidt, G. (1960). Brit. J. industr. Med. 17, 87.

S.M.R.E. (1961). Safety in Mines Research Establishment Annuzl Report for 1960 . p. 35 et seq. H.M.S.O., London.

Spink, R., and Nagelschmidt, G. (1963). Brit.J. industr. Med., 20, 118. Stegemann, H. (1958). Hoppe-Seyler's Z. physiol. Chem., 311, 41.

Watson, A. J., Black, J., Doig, A. T., and Nagelschmidt, G. (1959). Brit. J. industr. Med., 16, 274.

Wells, Arit. J. (1954). J. Path. Bact., 68, 573. Zaidi, S. H., Harrison, C. V., King, E. J., and Mitchison, D. A. (1955). 